\title{
Lactic acid bacteria: a promising alternative for recombinant protein production
}

\author{
Elena García-Fruitós ${ }^{1,2}$
}

Even though the use of Lactic Acid Bacteria (LAB) is well documented for a variety of dairy food fermentation dating back to the earliest written records $[1,2]$, the use of these Gram-positive anaerobic microorganisms as recombinant microbial cell factories has taken place during the last decades. In this context, it is important to note that the enormous potential of these Generally Recognized As Safe (GRAS) organisms by the US Food and Drug Administration combined with the development of biotechnological, genomic and proteomic tools experienced during last years are expected to convert these microorganisms in emerging platforms for a wide range of applications [2,3]. Nowadays it is widely accepted that LAB-derived products from the industrial manufacture of fermented food such as milk products, vegetables, meat and wine $[4,5]$, as well as lactic acid, antimicrobial peptides and high-value metabolites, are by far the most important LAB applications from an economical point of view. Besides, the use of these organisms as probiotics has also experienced an important increase in the last decades [6-10]. However, it is also important to stress that LAB characteristics make these organisms an ideal bacterial expression system for both homologous and heterologous proteins, including membrane proteins [11]. Interestingly, apart from the cheap and easily scalable protein production associated to the microbial nature of $L A B$, these species are foodgrade expression hosts, that, contrary to what occurs in Gram-negative bacteria, do not contain endotoxins in their membrane, which are pyrogenic in humans and other mammals [12-14]. In this context, although E. coli is still the first-choice microorganism for the production of heterologous proteins, this species presents several obstacles, including, as mentioned, the presence of endotoxins in its derived products, limiting its final application as cell factory for the production of

Correspondence: efruitos@ciber-bbn.es

${ }^{1}$ Institut de Biotecnologia i de Biomedicina, Universitat Autònoma de Barcelona, Bellaterra (Cerdanyola del Vallès), Barcelona, Spain

${ }^{2}$ CIBER de Bioingeniería, Biomateriales y Nanomedicina (CIBER-BBN), Bellaterra (Cerdanyola del Vallès), Barcelona, Spain recombinant proteins, particularly those with pharmaceutical interest [15-17]. Thus, considering the limitations imposed by the use of E. coli, in the last years an increasing number of scientists are considering Grampositive bacteria as a much optimal and safer microbial alternative for recombinant protein production. In fact, it is already possible to find commercially available enzymes produced in Gram-positive microorganisms [13]. Actually, Bacillus subtilis is nowadays one of the most used Gram-positive bacteria for the production of industrial enzymes, most of them being prokaryotic proteins [18]. Interestingly, B. subtilis is not only a convenient cell factory for the generation of safe products, but it also has an excellent secretion system, contrary to what occurs in E. coli, simplifying downstream processing of the protein and becoming a really interesting alternative $[13,19]$. Besides, several studies are being performed concerning B. subtilis quality control system, an approach that will significantly improve the successful production of difficult-to-express proteins in Gram-positive microorganisms in a near future $[12,20]$. Thus, Grampositive bacteria are clearly promising candidates for the production of membrane and complex proteins, one of the most important challenges in Biotechnology, since these proteins are among the most significant drug targets. However, it should be mentioned that most of the efforts using safe hosts for recombinant protein production have been focused to the generation of recombinant homologous proteins and essentially using B. subtilis, being now time to extend our activities on the vast group of LAB for the production of heterologous proteins, those with a higher impact in Pharma and Biotech industries. In this context, the increasing interest on LAB has prompted researchers to develop key tools for recombinant protein production, such as suitable expression vectors, optimal promoters, modified strains and improved induction and secretion systems $[1,11,18,21,22]$. Interestingly, although recombinant protein production in LAB is far from being an extensively explored field, being much of their possibilities still to 
come to the surface, there are already examples in the literature showing the great potential of this safe expression system.

On the one hand, Lactococcus lactis has been described as another promising LAB in terms of recombinant protein production $[18,21]$. In this regard, Glenting and coworkers have shown that L. lactis can be a useful allergen expression system not only able to overcome the problems associated to the natural source extraction (low batch-to-batch variation, allergen preparations with defined purity and composition, among others), but also due to the safety of the isolated products [23]. Thus, recombinant production of genetically engineered hypoallergens for immunotherapy purposes is just an example of the high capacity of this group of LAB. Other examples describe the successful production of biologically active murine interferon-gamma, a cytokine that is commonly found forming inclusion bodies when expressed in E. coli [24], and a staphylococcal nuclease with biotechnological interest [22], published by Bermúdez-Humarán and collaborators and Tremillon and coworkers, respectively. Other publications prove that L. lactis is not only a good candidate for the heterologous production of both cytoplasmic and secreted proteins, but also an ideal alternative as a live bacterial vector able to efficiently deliver antigenic or therapeutic proteins at the mucosal level [21,25]. A review recently published by Bahey-El-Din and coworkers summarizes the already tested applications of L. lactis as expression host to deliver proteins with biomedical interest [26]. Analyzing the more than 40 different examples published in this paper, it is possible to conclude that L. lactis has successfully been used when delivering bacterial, viral and protozoal antigens and also therapeutic proteins from different origins including murine, human, ovine, rat and bovine [26]. Thus, these promising results consolidate the potential of $L$. lactis as a new vaccine delivery platform. Moreover, these data are also a clear prove of the potential of this group of Gram-positive bacteria for the production of both homologous and heterologous proteins, opening an amazing range of possibilities in the recombinant protein production field. Besides, since LAB are also able to produce biomolecules other than proteins, these microorganisms, and more specifically Lactobacillus genera, has also efficiently been explored as candidates for the delivery of functional agents and food ingredients for the production, among others, of gluten free bread with improved properties [27].

In summary, although many of the applications of $\mathrm{LAB}$ as a host factory need to be further explored, the already proved safety profile and efficiency of this expression system draw a promising future of GRAS organisms as the expression system of choice that can revolutionize the field of recombinant protein production.

Received: 4 December 2012 Accepted: 11 December 2012

Published: 12 December 2012

\section{References}

1. Pontes DS, de Azevedo MS, Chatel JM, Langella P, Azevedo V, Miyoshi A: Lactococcus lactis as a live vector: heterologous protein production and DNA delivery systems. Protein Expr Purif 2011, 79:165-175.

2. de Vos WM: Systems solutions by lactic acid bacteria: from paradigms to practice. Microb Cell Fact 2011, 10(Suppl 1):S2

3. Teusink B, Bachmann H, Molenaar D: Systems biology of lactic acid bacteria: a critical review. Microb Cell Fact 2011, 10(Suppl 1):S11.

4. Konings WN, Kok J, Kuipers OP, Poolman B: Lactic acid bacteria: the bugs of the new millennium. Curr Opin Microbiol 2000, 3:276-282.

5. Rhee SJ, Lee JE, Lee CH: Importance of lactic acid bacteria in Asian fermented foods. Microb Cell Fact 2011, 10(Suppl 1):S5

6. Mills S, Stanton C, Fitzgerald GF, Ross RP: Enhancing the stress responses of probiotics for a lifestyle from gut to product and back again. Microb Cell Fact 2011, 10(Suppl 1):S19.

7. Forssten SD, Sindelar CW, Ouwehand AC: Probiotics from an industrial perspective. Anaerobe 2011, 17:410-413.

8. Kumari A, Catanzaro R, Marotta F: Clinical importance of lactic acid bacteria: a short review. Acta Biomed 2011, 82:177-180.

9. Wells JM: Immunomodulatory mechanisms of lactobacilli. Microb Cell Fact 2011, 10(Suppl 1):S17.

10. Gleinser M, Grimm V, Zhurina D, Yuan J, Riedel CU: Improved adhesive properties of recombinant bifidobacteria expressing the Bifidobacterium bifidum-specific lipoprotein BopA. Microb Cell Fact 2012, 11:80.

11. Douillard FP, O'Connell-Motherway M, Cambillau C, van Sinderen D: Expanding the molecular toolbox for Lactococcus lactis: construction of an inducible thioredoxin gene fusion expression system. Microb Cell Fact 2011, 10:66.

12. Zweers JC, Barak I, Becher D, Driessen AJ, Hecker M, Kontinen VP, et al: Towards the development of Bacillus subtilis as a cell factory for membrane proteins and protein complexes. Microb Cell Fact 2008, 7:10.

13. Westers L, Westers H, Quax WJ: Bacillus subtilis as cell factory for pharmaceutical proteins: a biotechnological approach to optimize the host organism. Biochim Biophys Acta 2004, 1694:299-310.

14. Petsch D, Anspach FB: Endotoxin removal from protein solutions. J Biotechnol 2000, 76:97-119.

15. Ferrer-Miralles N, Domingo-Espin J, Corchero JL, Vazquez E, Villaverde A: Microbial factories for recombinant pharmaceuticals. Microb Cell Fact 2009, 8:17.

16. Schmidt FR: Recombinant expression systems in the pharmaceutical industry. Appl Microbiol Biotechnol 2004, 65:363-372.

17. Liu S, Tobias R, McClure S, Styba G, Shi Q, Jackowski G: Removal of endotoxin from recombinant protein preparations. Clin Biochem 1997 30:455-463.

18. Morello E, Bermudez-Humaran LG, Llull D, Sole V, Miraglio N, Langella P, et al. Lactococcus lactis, an efficient cell factory for recombinant protein production and secretion. J Mol Microbiol Biotechnol 2008, 14:48-58.

19. Papagianni M: Recent advances in engineering the central carbon metabolism of industrially important bacteria. Microb Cell Fact 2012, 11:50.

20. Marciniak BC, Trip H, van-der Veek PJ, Kuipers OP: Comparative transcriptional analysis of bacillus subtilis cells overproducing either secreted proteins, lipoproteins or membrane proteins. Microb Cell Fact 2012, 11:66

21. Nouaille S, Ribeiro LA, Miyoshi A, Pontes D, Le LY, Oliveira SC, et al. Heterologous protein production and delivery systems for Lactococcus lactis. Genet Mol Res 2003, 2:102-111.

22. Tremillon N, Issaly N, Mozo J, Duvignau T, Ginisty H, Devic E, et al. Production and purification of staphylococcal nuclease in Lactococcus lactis using a new expression-secretion system and a pH-regulated mini-reactor. Microb Cell Fact 2010, 9:37.

23. Glenting J, Poulsen LK, Kato K, Madsen SM, Frokiaer H, Wendt C, et al. Production of recombinant peanut allergen Ara $\mathrm{h} 2$ using lactococcus lactis. Microb Cell Fact 2007, 6:28. 
24. Bermudez-Humaran LG, Cortes-Perez NG, L'Haridon R, Langella P: Production of biological active murine IFN-gamma by recombinant Lactococcus lactis. FEMS Microbiol Lett 2008, 280:144-149.

25. Bahey-El-Din M, Gahan CG: Lactococcus lactis-based vaccines: current status and future perspectives. Hum Vaccin 2011, 7:106-109.

26. Bahey-El-Din M, Gahan CG, Griffin BT: Lactococcus lactis as a cell factory for delivery of therapeutic proteins. Curr Gene Ther 2010, 10:34-45.

27. Arendt EK, Moroni A, Zannini E: Medical nutrition therapy: use of sourdough lactic acid bacteria as a cell factory for delivering functional biomolecules and food ingredients in gluten free bread. Microb Cell Fact 2011, 10(Suppl 1):S15.

doi:10.1186/1475-2859-11-157

Cite this article as: García-Fruitós: Lactic acid bacteria: a promising

alternative for recombinant protein production. Microbial Cell Factories 2012 11:157.

\section{Submit your next manuscript to BioMed Central and take full advantage of:}

- Convenient online submission

- Thorough peer review

- No space constraints or color figure charges

- Immediate publication on acceptance

- Inclusion in PubMed, CAS, Scopus and Google Scholar

- Research which is freely available for redistribution 